\title{
Pengaruh Media Pembelajaran Multimedia Berbasis Flash Player Terhadap Hasil Belajar Siswa Pada Mata Pelajaran Fiqh Kelas V Di Madrasah Ibtidaiyah Muhammadiyah 15 Banjarwati Paciran.
}

\author{
M. Chotibuddin \\ Sekolah Tinggi Ilmu Tarbiyah Muhammadiyah Paciran Lamongan, Indonesia \\ Email: boedz2012@gmail.com
}

\begin{abstract}
The application of media in the learning process is one way that can be used to realize achievement and learning outcomes. Because learning media is one thing that absolutely exists in the learning process. Interactive multimedia-based learning is one source of learning based on Information and Communication Technology (ICT). The purpose of this research was to analyze the effect of flash player-based multimedia learning media on learning outcomes. Students in the fifth grade on Fiqh subject at MI Muhammadiyah 15 Banjarwati Paciran.

The research design used is One Groups Pretest-Posttest Design with saturated sample sampling technique. The number of samples is 22.

The results showed that the average prettest score (before being given the media) was (60.23) while the posttest average was (69.55). According to the t-test calculation, it was obtained tcount (5.52) > ttable (2,086), so it can be said that the flash player-based multimedia learning method is effective and significant on student learning outcomes in the subject matter of Hajj in the fifth grade at MI Muhammadiyah 15 banjarwati paciran for the academic year 2020/2021.

This proves that there is difference between learning outcomes in Fiqh subjects on the subject matter of Hajj before and before using multimedia-based learning media using Adobe Flash.
\end{abstract}

Keywords : learning media, Adobe Flash player, multimedia based-learning, learning outcomes.

\section{Pendahuluan}

Dewasa ini pendidikan merupakan salah satu aspek terpenting dalam meningkatkan sumber daya manusia di era globalisasi ini dan memegang peranan penting dalam kemajuan suatu bangsa. Peningkatan mutu pembelajaran juga berpengaruh terhadap keberhasilan dalam belajar di sekolah yang mana di sini guru sebagai pendidik dan maupun pengajar. Menurut UU No. 20 Tahun 2003 pasal 3 Tentang Sistem Pendidikan Nasional, tujuan pendidikan nasional adalah untuk mengembangkan potensi peserta didik agar menjadi manusia yang beriman dan bertakwa kepada Tuhan Yang Maha Esa, berakhlak mulia, sehat, berilmu, cakap, kreatif, mandiri, dan menjadi warga negara yang demokratis serta bertanggung jawab.

Begitu pentingnya peran guru dalam mentransformasikan input-input pendidikan, maka guru harus selalu mempunyai metode yang baik dalam proses 


\section{Chotibuddin}

pembelajarannya. Penggunaan media dalam proses pembelajaran merupakan salah satu cara yang dapat digunakan untuk mewujudkan prestasi dan hasil belajar. Karena media pembelajaran merupakan salah satu hal yang mutlak ada dalam proses pembelajaran. "Media apabila dipahami secara garis besar adalah manusia, materi atau kejadian yang membangun kondisi yang membuat peserta didik mampu memperoleh pengetahuan, keterampilan atau sikap (Gerlach dan Ely, 1971. p.89). Pembelajaran berbasis multimedia interaktif merupakan salah satu sumber belajar yang berbasis Teknologi Informasi dan Komunikasi (TIK). Media pembelajaran ini menggabungkan teks, gambar, grafis, animasi, audio dan video serta cara penyampaian interaktif yang dapat membuat suatu pengalaman belajar bagi peserta didik seperti dalam kehidupan nyata di sekitarnya (Winarno, dkk. 2009. P.8). Multimedia pembelajaran interaktif berisi bahan ajar dalam bentuk instruksi dan narasi dengan sistem komunikasi interaktif berbasis stimulus respon, disajikan secara terstruktur dan sistematis sesuai kurikulum yang berlaku.

Perkembangan ilmu pengetahuan dan teknologi yang semakin canggih, diharapkan dapat dimanfaatkan dalam pembelajaran. Selain media sebagai penunjang proses belajar mengajar, guru juga dituntut agar mampu menggunakan alat-alat yang tersedia, guru juga dituntut mempunyai ketrampilan dan keahlian untuk mengembangkan media pengajaran yang belum tersedia (Ashar Arsyad.2000. p.2).

Guru seharusnya mempunyai pengaruh yang sangat besar pada terciptanya proses dan hasil pembelajaran yang berkualitas sehingga bisa mencapai tujuannya yaitu hasil belajar, namun hingga sekarang di MI Muhammadiyah 15 Banjarwati belum berjalan dengan baik. Hal ini terlihat pada kurangya guru dalam persiapan pembelajaran di kelas dan metode pengajaran cenderung masih tradisional, tentu saja ini membuat materi Fiqh di mata siswa jadi kurang menarik, sehingga berpengaruh terhadap hasil belajar siswa.

Berdasarkan paparan di atas peneliti ingin membuat siswa mudah memahami suatu materi yang disampaikan guru dan mencapai hasil belajar yang maksimal. Penggunaan metode pembelajaran multimedia berbasis flash player dianggap sangat tepat untuk membantu mempermudah peserta didik memahami materi yang ada dan menggapai hasil belajar yang diinginkan.

\section{Rumusan Masalah}


Berdasarkan uraian latar belakang di atas, dapat ditarik beberapa rumusan permasalahan sebagai berikut : "Adakah pengaruh media pembelajaran multimedia berbasis flash player terhadap hasil belajar siswa pada mata pelajaran Fiqh kelas V di MI Muhammadiyah 15 Banjarwati Paciran?"

\section{Landasan TEORI}

\section{Pengertian Media}

Association for Education and Communication Technology (AECT) mendefinisikan media adalah segala bentuk yang dipergunakan untuk suatu proses penyaluran informasi. "Media apabila dipahami secara garis besar adalah manusia, materi dan kejadian yang membangun kondisi yang membuat siswa mampu memperoleh pengetahuan, keterampilan atau sikap (erlach dan Ely, 1971. P.89)

\section{Posisi Media}

Proses pembelajaran merupakan proses komunikasi dan berlangsung dalam suatu sistem, maka media pembelajaran menempati posisi yang cukup penting sebagai salah satu komponen sistem pembelajaran. Tanpa media, komunikasi tidak akan terjadi dan proses pembelajaran sebagai proses komunikasi juga tidak akan bisa berlangsung secara optimal. Media pembelajaran adalah komponen integral dari system pembelajaran.

\section{Fungsi dan Manfaat Media}

Dalam proses pembelajaran, media memiliki fungsi sebagai pembawa informasi dari sumber (guru) menuju penerima (siswa). Sedangkan metode adalah prosedur untuk membantu siswa dalam menerima dan mengolah informasi guna mencapai tujuan pembelajaran (Wayan. 2007. P.4).

\section{Jenis-jenis Media pembelajaran}

Media pembelajaran Media pembelajaran juga merupakan komponen intruksional yang meliputi pesan, orang, dan peralatan. Yaitu wahana penyalur informasi belajar atau informasi pesan. Media pembelajaran banyak sekali jenis dan macamnya. Kita bisa memanfaatkan berbagai jenis media yang ada untuk menunjang proses belajar, apalagi di zaman sekarang ini peran teknologi sudah terasa dan telah masuk ke berbagai aspek, termasuk dunia pendidikan. Berikut ini adalah jenis-jenis media pembelajaran, sebagai berikut:

1. Media yang tidak diproyeksikan

2. Media yang diproyeksikan 


\section{Chotibuddin}

3. Media audio

4. Media Video

5. Media berbasis komputer

6. Multimedia (Ariani, N., \& Haryanto, D. 2010. P.90)

Media yang akan dibahas dan digunakan dalam penelitian pengembangan ini adalah multimedia pembelajaran berbasis Flash player. Multimedia pembelajaran Flash playersudah mencakup semua jenis media yang ada dari beberapa media.

\section{Flash Player}

Pengertian Adobe Flash Player Profesional Flash CS6 merupakan sebuah aplikasi yang dapat dimanfaatkan untuk membuat animasi 2 dimensi yang ringan dan handal sehingga banyak digunakan untuk membangun dan memberikan efek animasi pada website, CD interaktif dan lainnya. Adobe flash CS6 merupakan aplikasi yang cocok untuk keperluan pembuatan sebuah media pembelajaran, karena aplikasi tersebut mudah digunakan selain itu tidak memerlukan spesifikasi komputer yang canggih untuk bisa menggunakannya. Aplikasi ini menyediakan berbagai macam fitur yang akan sangat membantu para animator untuk membuat animasi yang mudah dan menarik (Hendro saputro. 2015. P.10). Pada media pembelajaran berbasis Adobe Flash materi Prinsip Desain ini memiliki keunggulan yakni tombol navigasi berupa flat-icon 2D, gambar desain corel draw, gambar desain manual dengan teknik warna kering, video, audio, soal evaluasi interaktif, dan tipe ukuran softwarenya.

\section{Pengertian Hasil belajar}

Hasil belajar adalah sebagai terjadinya perubahan tingkah laku pada diri seseorang yang dapat diamati dan diukur bentuk pengetahuan, sikap dan keterampilan. Perubahan tersebut dapat diartikan sebagai terjadinya peningkatan dan pengembangan yang lebih baik dari sebelumnya dan yang tidak tahu menjadi tahu (Omear Hamalik. 2007. P.30).

\section{Faktor- faktor yang mempengaruhi hasil belajar}

Keberhasilan belajar tidak saja ditentukan oleh peningkatan kemampuan para pendidiknya saja, akan tetapi ditentukan oleh faktor-faktor yang lain yang saling mempengaruhi satu dengan yang lain, sebagaimana Oemar Hamalik mengemukakan beberapa faktor kesulitan belajar siswa antara lain:

a. Faktor-faktor yang berfungsi dari diri sendiri

b. Faktor-faktor yang bersumber dari lingkungan. 
c. Faktor-faktor yang bersumber dari lingkungan keluarga

d. Faktor-faktor yang bersumber dari lingkungan masyarakat (Omear Hamalik. 2007. P.117).

Dengan demikian dapat diketahui bahwa faktor-faktor yang merupakan kesulitan belajar yang dialami peserta didik perlu adanya bantuan dan bimbingan guna meningkatkan prestasi belajar siswa dan terhindar dari kesulitan belajar yang dialami siswa dan akhirnya dapat dicapai prestasi belajar yang optimal.

\section{Metode Penelitian}

Berdasarkan judul yang telah dikemukakan yaitu pengaruh metode pembelajaran multimedia berbasis Adobe Flash player terhadap hasil belajar siswa pada mata pelajaran Fiqh kelas V di MI Muhammadiyah 15 Banjarwati, maka dapat disimpulkan penelitian ini merupakan penelitian kuantitatif dengan metode eksperimental. Yaitu metode pengukuran antar variabel pada sebelum dan sesudahnya untuk melihat hubungan sebabakibat dari fenomena yang diteliti. dengan pendekatan desain atau metodenya adalah “One Groups Pretest-Posttest Design", yaitu desain penelitian yang terdapat pretest sebelum diberi perlakuan dan posttest setelah diberi perlakuan. Dengan demikian dapat diketahui lebih akurat, karena dapat membandingkan dengan diadakan sebelum diberi perlakuan (Sugiyono. 2001. P.64).

\section{Sumber data}

\section{Populasi}

Populasi adalah keseluruhan subjek penelitian (Suharsimi Arikunto. 2006. P.130). dalam penelitian ini penulis menentukan objek penelitian yaitu seluruh siswa kelas $\mathrm{V}$ MI Muhammadiyah 15 Banjarwati, Paciran pada tahun pelajaran 2020/2021 yang berjumlah 22 siswa.

\section{Sampel}

Sampel sebagaian atau wakil populasi yang diteliti (Suharsimi Arikunto. 2006. P.131). Sampel pada penelitian ini menggunakan metode pengambilan teknik sampling jenuh, yaitu teknik penentuan sampel bila semua anggota digunakan sebagai sampel.

\section{Teknik Pengumpulan data}




\section{Chotibuddin}

Tehnik pengumpulan data adalah Metode untuk memperoleh data-data (Sutrisno Hadi. 1987. P.67). Dalam hal ini tehnik-tehnik yang digunakan dalam mengumpulkan data adalah sebagai berikut:

\section{Metode Tes}

Tes adalah merupakan alat atau prosedur yang digunakan untuk mengetahui atau mengukur sesuatu dalam suasana, dengan cara dan aturan-aturan yang sudah ditentukan (Suharsimi Arikunto. 2006. P.53).

\section{Metode dokumentasi}

Metode dokumentasi adalah metode yang digunakan peneliti untuk memperoleh informasi dengan jalan menyelidiki benda- benda tertulis seperti buku-buku, majalah, dokumen, peraturan- peraturan, notulen rapat, catatan harian, dan sebagainya (Suharsimi Arikunto. 2006. P.158). Metode observasi

Metode observasi adalah metode yang digunakan peneliti untuk memperoleh informasi dengan jalan melakukan pengamatan Iangsung ke lapangan. Metode ini digunakan untuk meneliti keadaan madrasah meliputi, letak geografis, keadaan gedung, dan hal- hal lain yang relevan.

\section{Instrumen penelitian}

Untuk memperoleh data yang benar- benar valid dan menghindari kekeliruan dalam mengambil data penelitian maka dibutuhkan alat ukur (Instrumen) penelitian. instrumen adalah alat pada waktu penelitian menggunakan metode penelitian (Suharsimi Arikunto. 2006. P.149). Tes, Instrumen tes yang digunakan dalam penelitian ini merupakan tes tertulis dengan jenis tes objektif Pada tes objektif, bentuk tes yang digunakan adalah bentuk pilihan ganda.

Dokumentasi, Dengan metode ini peneliti mengambil data-data yang mengenai sekolah dan pembelajaran Fiqh seperti Rpp, daftar hadir, nilai mata pelajaran Fiqh V MI Muhammadiyah 15 Banjarwati Paciran Lamongan.

Observasi, Dalam hal ini peneliti menggunakan observasi sistematis yaitu mengadakan pengamatan secara langsung ke MI Muhammadiyah 15 Banjarwati Paciran Lamongan. untuk mengamati perilaku peserta didik kelas V MI Muhammadiyah 15 Banjarwati Paciran Lamongan.

\section{Tehnik analisis data}

Uji Validitas 
Validitas merupakan suatu ukuran yang menunjukkan tingkat kevalidan suatu instrumen. Suatu instrument yang valid akan mempunyai validitas yang tinggi sebaliknya suatu instrument yang kurang valid akan mempunyai validitas yang rendah. Adapun rumus validitas yang digunakan adalah rumus korelasi Person Product Moment, dengan rumus sebagai berikut :

Keterangan :

$$
r_{x y}=\frac{n \cdot \sum X Y-\left(\sum X\right)\left(\sum Y\right)}{\sqrt{\left(n \cdot \sum X^{2}\right)-\left(\sum X\right)^{2}\left(n \cdot \sum Y^{2}\right)-\left(\sum Y\right)^{2}}}
$$

$$
\begin{aligned}
& r_{x y}=\text { Koefisien korelasi antara } \\
& \text { variabel } \mathrm{X} \text { dan variabel } \mathrm{Y} \\
& n \quad=\text { Jumlah responden } \\
& \sum X Y=\text { Jumlah perkalian antara } \\
& \text { nilai } X \text { dan } Y \\
& \sum X=\text { Jumlah nilai } \mathrm{X} \\
& \sum Y=\text { Jumlah nilai } \mathrm{Y} \\
& \sum X^{2}=\text { Jumlah kuadrat nilai } \mathrm{X} \\
& \sum Y^{2}=\text { Jumlah kuadrat nilai } \mathrm{Y}
\end{aligned}
$$

Syarat minimum untuk dianggap suatu butir instrument valid adalah nilai indeks valid adalah nilai indeks validitasnya $\geq 0,3$ (Sugiyono. 2016. 179). Oleh karena itu, semua pernyataan yang memiliki tingkat korelasi dibawah 0,3 harus diperbaiki karena dianggap tidak valid.

\section{Uji Reliabilitas}

Uji reliabilitas adalah sejauh mana hasil pengukuran dengan menggunakan objek yang sama akan menghasilkan data yang sama (Sugiyono. 2013. P.121). Adapun rumus untuk mencari reliabelitas adalah menggunakan rumus KR-20, dengan rumus sebagai berikut:

$$
r_{11}=\left(\frac{n}{n-1}\right)\left(\frac{s_{t}^{2}-\sum p_{i} q_{i}}{s_{t}^{2}}\right)
$$

Ketereangan :

$$
\begin{aligned}
& n=\text { Jumlah butir soal } \\
& s_{t}^{2}=\text { varian skor }
\end{aligned}
$$




$$
\sum p_{i} q_{i}=\text { jumlah total } p q
$$

Setelah di dapat nilai reliabilitas ( $r_{\text {hitung }}$ ) maka nilai tersebut dibandingkan dengan yang sesuai dengan jumlah responden dan taraf nyata dengan ketentuan sebagai berikut: Bila:

$$
\begin{aligned}
& \text { Bila } \quad r_{\text {hitung }} \geq r_{\text {tabel }}: \quad \text { Instrument tersebut dikatakan reliabel } \\
& \text { Bila } r_{\text {hitung }} \leq r_{\text {tabel }}: \text { Instrument tersebut dikatakan tidak reliabel }
\end{aligned}
$$

\section{Uji Normalitas}

Uji normalitas digunakan untuk mengetahui kondisi data apakah berdistribusi normal atau tidak. Kondisi data berdistribusi normal menjadi syarat menemukan uji-t yang digunakan. Di sini peneliti menggunakan rumus saphiro wilk, adapun alasan peneliti menggunakan rumus saphiro wilk karena jumlah sampel yang relatif kecil (kurang dari 50 ).

\section{Uji Homogenitas}

Data pretest dan posttest diuji homogennya. Hal ini bertujuan untuk mengetahui apakah kedua data tersebut memiliki varians yang sama atau tidak. Dalam penelitian ini digunakan uji $\mathrm{F}$ dengan varians terbesar dibanding varians terkecil menggunakan Tabel F.

Adapun untuk rumus cara mencari varians defisiansi $\mathrm{X}$ adalah sebagai berikut:

$$
\mathrm{Sx}=\frac{\sqrt{N \sum x^{2}-\left(\sum x\right)^{2}}}{N(N-1)}
$$

keterangan:

$$
\begin{aligned}
& \mathrm{N}=\text { jumlah responden } \\
& \sum \mathrm{x}^{2}=\text { Jumlah nilai } \mathrm{x} \text { kuadrat } \\
& \left(\sum \mathrm{x}\right)^{2}=\text { Jumlah nilai } \mathrm{x}
\end{aligned}
$$

Sedangkan rumus untuk mencari varians defisiansi Y adalah:

$$
\text { Sy }=\frac{\sqrt{N \sum y^{2}-\left(\sum y\right)^{2}}}{N(N-1)}
$$

Keterangan: 


$$
\begin{aligned}
& \mathrm{N}=\text { Jumlah responden } \\
& \sum \mathrm{y}^{2}=\text { Jumlah nilai y kuadrat } \\
& \left(\sum \mathrm{y}\right)^{2}=\text { Jumlah nilai y }
\end{aligned}
$$

Setealah Varians $\mathrm{X}$ dan $\mathrm{Y}$ sudah ditemukan, selanjutnya dihitung dengan menggunakan rumus berikut:

$$
F_{\text {hitung }}=\frac{\text { varian terbesar }}{\text { varian terkecil }}
$$

\section{Uji Hipotesis}

Uji korelasi pearson product moment

Uji Korelasi pearson product moment ( $r$ ) digunakan untuk mengetahui derajat hubungan dan kontribusi variabel bebas (independent) dengan variabel terikat (dependent), dengan menggunakan rumus korelasi pearson product moment ( $r$ ) sebagai berikut:

$$
r_{x y}=\frac{n \cdot \sum X Y-\left(\sum X\right)\left(\sum Y\right)}{\sqrt{\left(n \cdot \sum X^{2}\right)-\left(\sum X\right)^{2}\left(n \cdot \sum Y^{2}\right)-\left(\sum Y\right)^{2}}}
$$

Ketereangan:

$$
\begin{array}{ll}
\begin{array}{ll}
r_{x y} & = \\
\text { variabel } & \mathrm{X} \text { dan variabel } \mathrm{Y} \\
n \quad & =\text { Jumlah responden } \\
\sum X Y \quad & =\text { Jumlah perkalian antara } \\
\text { nilai } & \mathrm{X} \text { dan } \mathrm{Y} \\
\sum X \quad & \text { Jumlah nilai } \mathrm{X} \\
\sum Y \quad & \text { Jumlah nilai } \mathrm{Y} \\
\sum X^{2} & =\text { Jumlah kuadrat nilai } \mathrm{X} \\
\sum Y^{2} & =\text { Jumlah kuadrat nilai } \mathrm{Y}
\end{array}
\end{array}
$$




\section{Chotibuddin}

\section{Uji Signifikansi (uji-t)}

Uji signifikasi digunakan untuk mengetahui ada tidak pengaruh signifikan antara dua variabel, yaitu variabel independen dan variabel dependen. dengan menggunakan rumus sebagai berikut:

$$
t=\frac{r \sqrt{n-2}}{\sqrt{1-r^{2}}}
$$

Keterangan:

$$
\begin{array}{ll}
\mathrm{t} & =\text { Nilai uji } \mathrm{t} \\
r & =\text { Koefision korelasi pearson } \\
r^{2} & =\text { Koefision determinasi } \\
n & =\text { jumlah sampel }
\end{array}
$$

Dalam pengolahan uji statistik $\mathrm{t}$ bertujuan untuk melihat seberapa besar pengaruh variabel independen terhadap variabel dependen secara individu . Uji ini dilakukan dengan syarat:

A. Jika t hitung < ttabel, maka hipotesis tidak teruji yaitu variabel independen berpengaruh tidak signifikan terhadap variabel dependen.

B. Jika thitung > ttabel, maka hipotesis teruji yang berarti variabel independen berpengaruh signifikan terhadap variabel dependen.

\section{Hasil Penelitian}

\section{Penyajian data}

Untuk mendapatkan data tentang pengaruh dari metode pembelajaran multimedia berbasis flash player terhadap hasil belajar siswa. peneliti melakukan pengambilan data dengan memberikan soal pretest dan posttest kepada responden di kelas V MI Muhammadiyah 15 Banjarawti yang mana berjumlah 22 responden .

Tabel 1 Nilai Pretest (X) dan Nilai Posttest (Y)

\begin{tabular}{|c|c|c|}
\hline \multirow{2}{*}{ NO } & \multicolumn{2}{|c|}{ Nilai } \\
\cline { 2 - 3 } & $\begin{array}{c}\text { pretest } \\
(\mathrm{X})\end{array}$ & postest (Y) \\
\hline 1 & 50 & 80 \\
\hline 2 & 70 & 75 \\
\hline 3 & 60 & 75 \\
\hline 4 & 70 & 100 \\
\hline 5 & 60 & 100 \\
\hline
\end{tabular}




\begin{tabular}{|c|c|c|}
\hline 6 & 70 & 60 \\
\hline 7 & 70 & 85 \\
\hline 8 & 70 & 75 \\
\hline 9 & 65 & 60 \\
\hline 10 & 70 & 45 \\
\hline 11 & 90 & 90 \\
\hline 12 & 70 & 85 \\
\hline 13 & 95 & 95 \\
\hline 14 & 85 & 100 \\
\hline 15 & 40 & 30 \\
\hline 16 & 30 & 30 \\
\hline 17 & 20 & 35 \\
\hline 18 & 15 & 20 \\
\hline 19 & 85 & 90 \\
\hline 20 & 25 & 60 \\
\hline 21 & 35 & 60 \\
\hline 22 & 80 & 80 \\
\hline & 1325 & 1530 \\
\hline & 60.23 & 69.55 \\
\hline & 77\% & $41 \%$ \\
\hline & $23 \%$ & $59 \%$ \\
\hline
\end{tabular}

Dari Tabel di atas diperoleh data nilai pretest $(\mathrm{X})$ atau sebelum diberi perlakuan dengan nilai tertinggi sebesar 95 dan nilai terendahnya 15. Jumlah nilai dari 22 peserta didik sebesar 1325 dengan rata-rata yang diperoleh adalah 60.23. dapat disimpulkan bahwa 17 siswa dari 22 siswa masih belum mencapai KKM yang diterapkan yaitu 75 untuk pelajaran Fiqh Sedangkan nilai posttest (Y) setelah diberi perlakuan dengan nilai tertinggi sebesar 100 dan nilai terendah 20. Jumlah nilai dari 22 peserta didik sebesar 1530 dengan rata-rata yang diperoleh adalah 69.55. dengan demikian dapat simpulkan setelah diberi perlakuan (Y) jumlah siswa yang ditidak mencapai KKM turun dari 17 siswa menjadi 9 siswa.

\section{Analisis Data}

Uji Validitas 


\section{Chotibuddin}

Uji Validitas digunakan untuk mengetahui valid tidaknya item-item soal. valid tidaknya suatu item instrument penelitian dapat dilihat dengan membandingkan indeks korelasi product moment Pearson dengan nilai signifikansi 5\% dengan nilai kritis. Atau dengan kata lain dapat dibandingkan antara $r$ hitung dengan $r$ tabel untuk derajat kebebasan (degrees of freedom $/ \mathrm{df}$ ) $=\mathrm{n}-2$, dengan $\mathrm{n}=$ jumlah sampel. Hasil uji validitas data menunjukkan valid jika rhitung lebih besar dari rtabel. Pada penelitian ini jumlah sampel n $=22$ dan besar df adalah $22-2=20$ dengan taraf signifikansi 5\% diperoleh $\mathrm{r}$ tabel sebesar 0.444 .

\section{Uji Reliabilitas}

Uji reliabilitas digunakan untuk mengetahui tingkat konsistensi jawaban instrumen. Instrumen yang baik secara akurat memiliki jawaban konsisten kapanpun instrumen itu digunakan. Adapun Analisis reliabilitas tes pada penelitian ini diukur dengan menggunakan rumus KR-20.

Berdasarkan Hasil Perhitungan yang peneliti lakukan tentang uii reliabilitas pada instrumen butir soal pretest didapatkan $=0.847$, dengan taraf signifikan $5 \%$ dengan $=\mathrm{n}$ 2 , dengan $\mathrm{n}=$ jumlah sampel. Hasil uji reliabilitas data menunjukkan reliabel jika rhitung lebih besar dari rtabel. Pada penelitian ini jumlah sampel $n=22$ dan besar df adalah $22-2$ $=20$ dengan taraf signifikansi 5\% diperoleh $\mathrm{r}$ tabel sebesar 0,444. Setelah dibandingkan ternyata rhitung $>$ rtabel $=0.847>0.444$.

\section{Uji Normalitas}

Uji dilakukan untuk menentukan apakah data yang diperoleh berdistribusi normal atau tidak. Uji normalitas tersebut dilakukan dengan uji Shapiro-Wilk dengan menggunakan program SPSS 22 for Windows dengan taraf signifikansi 0,05.

Hasil Uji Normalitas Shapiro wilk:

\begin{tabular}{|c|c|c|c|}
\hline & \multicolumn{3}{|c|}{ Tests of Normality } \\
\hline & Statistic & $\mathrm{df}$ & Sig. \\
\hline PRETEST & .918 & 22 & .069 \\
\hline POSTEST & .917 & 22 & .065 \\
\hline
\end{tabular}

a. Lilliefors Significance Correction

Dengan pengambilan keputusan dalam uji normalitas shapiro-wilk:

a. Jika nilai Sig. $<0,05$ bahwa data berdistribusi normal ditolak, hal ini berarti data berdistribusi tidak normal 
b. Jika nilai Sig. > 0,05 maka H0 diterima. Hal ini berarti data tersebut berdistribusi normal

Berdasarkan hasil perhitungan uji normalitas Saphiro- Wilk dapat dilihat signifikansi pretest hasil belajar sebesar 0.069 dan posttes hasil belajar sebesar 0.065 . keduanya menunjukkan nilai signifikansi lebih dari 0.05 yang berarti H0 diterima. Berdasarkan itu maka dapat dikatakan bahwa butir soal pretest dan posttest berdistribusi normal.

\section{Uji Homogenitas}

Data pretest dan posttest diuji homogennya. Hal ini bertujuan untuk mengetahui apakah kedua data tersebut memiliki varians yang sama atau tidak. Dalam penelitian ini digunakan uji $\mathrm{F}$ dengan varians terbesar dibanding varians terkecil menggunakan Tabel $\mathrm{F}$. Berdasarkan hasil analisis uji di atas diperoleh $F_{\text {hitung }}$ sebesar 1.15 dan $F_{\text {tabel }}$ sebesar 2.08 jadi dapat disimpulkan bahwa $F_{\text {hitung }}<F_{\text {tabel }}(1,15<2.08)$. maka hal ini berarti kedua data pretest dan postest bersifat Homogen.

\section{Uji Hipotesis}

\section{Uji Korelai Product Moment}

Setelah diuji Normalitas dan Homogenitas datanya, kemudian data tersebut di uji korelasinya, di sini penulis menggunakan rumus korelasi product moment dari pearson. Dari hasil uji analisis korelasi dan tabel di atas dapat ditarik kesimpulan bahwa metode pembelajaran multimedia berbasis Flash Player dengan Hasil belajar Fiqh Terdapat Koefisien korelasi (r) sebesar 0.777 . Hal ini berarti bahwa ada hubugan korelasi antara media pembelajaran Flash Player dengan Hasil belajar Fiqh dengan dasar pengambilan keputusan menggunakan interpratasi Nilai r didapat tingkat Hubungan Tinggi.

Pada penelitian ini jumlah sampel $\mathrm{n}=22$ dan besar df adalah $22-2=20$ dengan taraf signifikansi 5\% diperoleh $\mathrm{r}$ tabel sebesar 0,444. Setelah dibandingkan ternyata rhitung $>$ rtabel $=0.777>0.444$. dengan demikian terdapat korelasi antara variabel $\mathrm{X}$ dan variabel Y.

\section{Uji signifikansi (Uji-T)}

Uji signifikansi (uji t) digunakan untuk menguji ada tidaknya Pengaruh indaktor- indikator media Pembelajaran flash player (X) terhadap hasil belajar siswa (Y). Berdasarkan Hasil perhitungan didapatkan $t_{\text {hitung }}$ sebesar 5.52 dan $t_{\text {tabel }}$ sebesar 2.086, maka dapat disimpulkan bahwa $t_{\text {hitung }}>t_{\text {tabel }}(5.52>2.086)$, maka secara parsial media 


\section{Chotibuddin}

pembelajaran flash player (x) berpengaruh signifikan terhadap hasil belajar siswa kelas 5 (Y) di MI Muhammadiyah 15 Banjarwati.

\section{Kesimpulan}

Berdasarkan penelitian yang telah dilakukan di MI Muhammadiyah 15 Banjarwati, Paciran. tahun ajaran 2020/2021 pada peserta didik kelas V materi haji diperoleh kesimpulan sebagai berikut: rata-rata nilai (pretest) sebelum diberi perlakukan sebesar 60.23 sedangkan sesudah diberi perlakuan (posttest) diperoleh nilai rata-rata sebesar 69.55. Pada uji korelasi yang telah dilakukan diperoleh kesimpulan bahwa terdapat Koefisien korelasi (r) sebesar 0.777 . Hal ini berarti bahwa ada hubugan korelasi antara media pembelajaran Flash Player dengan Hasil belajar Fiqh dengan dasar pengambilan keputusan menggunakan interpratasi Nilai $r$ didapat tingkat Hubungan Tinggi.

Pada uji kodensai di atas didapatkan $\mathrm{r}^{2}$ sebesar $0.60 \%$ Yang artinya terdapat pengaruh media pembelajaran flash terhadap hasil belajar sebesar $60 \%$ sedangkan sisanya $40 \%$ dipengaruhi oleh faktor-faktor lain. Sedangkan pada uji signifkansi atau uji t memberikan hasil $d k=21$ dan taraf signifikansi $\alpha=5 \%$ derajat kebebasan $(\mathrm{df})=\mathrm{n}-2=$ 22-2 = 20 maka diperoleh $t_{\text {tabel }}$ sebesar 2.086 dan $t_{\text {hitung }}$ sebesar 5.52 Hal tersebut menunjukkan bahwa $t_{\text {hitung }}>t_{\text {tabel }}(5.52>2.086$ ), yaitu menerima hipotesis penelitian.dengan kata lain, Metode pembelajaran multimedia berbasis flash player terhadap hasil belajar siswa berpengaruh signifikan.

Sehingga dapat disimpulkan bahwa Metode pembelajaran multimedia berbasis flash player efektif terhadap hasil belajar peserta didik pada mata pelajaran Fiqh pada materi pokok haji kelas V di MI Muhammadiyah 15 Banjarwati, Paciran tahun ajaran $2020 / 2021$.

\section{Daftar Pustaka}

Anna, Poedjiadi. 2005. Sains Teknologi Masyarakat: Model Pembelajaran Kontekstual. universitas pendidikan Indonesia

Arda, Saehan, \& Darsikin. 2015. Pengembangan Media Pmebelajaran interaktif berbasis Komputer untuk siswa kelas VIII. Tadulako: Universitas Tadulako Arikunto, Suharsimi. 2002. Dasar-Dasar Evaluasi Pendidikan. Jakarta: Bumi Aksara Arikunto,Suharsimi. 2006. Prosedur Penelitian, Jakarta: Rineka Cipta 
Azhar Arsyad. 2002. Media Pembelajaran, Jakarta: PT Rajagrafindo Persada

Dimyati Dan Mudjiono. 2009. Belajar Dan Pembalajaran, Jakarta: Rineka Cipta

Farida Hasan Rahmaibu. 2016. Pengembangan Media Pembelajaran Berbasis Multimedia dengan Menggunakan Adobe Flash untuk Meningkatkan Hasil Belajar PKn Studi Kasus: SDI Al-Madina Semarang. Semarang: Program Sarjana Universitas Negeri Semarang

Gerlach dan Ely. 1971. Teaching dan media: A Systematic Approach, Baston: Second Edition, by V.S Gerlach \& D. P Ely.

Hadi, Sutrisno. 1987. Metodologi Rerearch. Yogyakarta: Andi Offset Hamalik, Omear. 2007. Proses Belajar Mengajar. Jakarta: Bumi Aksara. Himmatul Husniyah. 2021. Pengaruh Profesionalisme Guru Terhadap Peningkatan Prestasi Belajar Siswa Kelas X Di Madrasah Aliyah 02 Pondok Modern Paciran Lamongan. Jurnal Annaba STIT Muhammadiyah Paciran. Vol. 4 No. 1

Hendro saputro, Diana, Rusmala santi. 2015. Perangkat Ajar Dunia Hewan berbasis Multimedia, Bermuatan Nilai. Bandung: PT Remaja Rosda karya dan program Pascasarjana.

Idzi’ Layyinnati. 2018. Pengaruh Penerapan Media Benda Asli Pada Mata Pelajaran Matematika Terhadap Hasil Belajar Siswa Kelas 1 Di Madrasah Ibtidaiyah. Jurnal Annaba STIT Muhammadiyah Paciran. Vol. 7 No. 2

Idzi’ Layyinnati. 2021. Pengaruh Penggunaan Media Gambar Untuk Meningkatkan Hasil Belajar Bahasa Arab Siswa Kelas VII Di Madrasah Tsanawiyah 12 Palirangan. Jurnal Annaba STIT Muhammadiyah Paciran. Vol. 7 No. 1

Maftuhah. 2021. Pengaruh Metode Tanya Jawab Terhadap Prestasi Belajar Siswa Mata Pelajaran Akidah Akhlak Kelas IV Di Madrasah Ibtidaiyah Muhammadiyah 06 Brondong Lamongan. Jurnal Annaba STIT Muhammadiyah Paciran. Vol. 7 No. 1

Mardapi, Djemari. 2008. Teknik Penyusunan Instrument Tes Dan Nontes, Jogyakarta: Mitra Cendikia

Maya Fanny Furoidah, Pengaruh Penggunaan Media Animasi Pembelajaran Terhadap Hasil Belajar Siswa pada Mata Pelajaran Biologi Kelas VII MTS Surya Buana Malang

M. Chotibuddin. 2021. Pengaruh Metode Cooperative Type Jigsaw Terhadap Peningkatan Hasil Belajar Siswa Mata Pelajaran Pendidikan Agama Islam Di 


\section{Chotibuddin}

Kelas VI Madrasah Ibtidaiyah Muhammadiyah 09 Kranji Lamongan. Jurnal Annaba STIT Muhammadiyah Paciran. Vol. 7 No. 1

M. Chotibuddin. 2017. Penggunaan Metode Inkuiri Dalam Peningkatan Hasil Belajar Bahasa Inggris Di Kelas VII Madrasah Tsanawiyah Muhammadiyah 17 Paciran. Jurnal Annaba STIT Muhammadiyah Paciran. Vol. 3 No. 2

Ridwan \& Sunarto, 2009. Pengantar Statistika. Bandung: CV Alfa Beta

Subhan Adi Santoso. 2020. Media Pembelajaran Pendidikan Agama Islam Era Industri 4.0. Yogyakarta: Deepublish

Subhan Adi Santoso. M. Chotibuddin, 2020. Pembelajaran Blended Learning Masa Pandemi. Pasuruan: Qiara Media

Subhan Adi Santoso. Himmatul Husniyah, 2021. Pendidikan Agama Islam Berbasis IT. Yogyakarta: Zahir Publishing

Slavin. 1994. Model Pembelajaran Cooperatif Script. Jakarta: Airlangga.

Sugiyono, 2001. Metode Penelitian. Bandung: CV Alfa Beta.

Sugiyono. 2013. Metode Penelitian Kuantitatif, Kualitatif dan R\&D. Bandung: Alfabeta

Syinthia Kamala. 2016. Penggunaan Macromedia Flash Profesional 8 Dalam Pembelajaran Sejarah Kelas X IIS 1 SMA Negeri 2 Kalianda Tahun Pelajaran 2015/2016. Lampung: Program Sarjana Universitas Lampung 